\title{
PROFIL KEMAMPUAN KOMUNIKASI MATEMATIS SISWA DALAM MENYELESAIKAN MASALAH GEOMETRI DITINJAU DARI LEVEL VAN HIELE
}

\author{
Imania Aufi Akalili ${ }^{1}$, Sunardi $^{2}$, Lioni Anka Monalisa ${ }^{2}$, Didik Sugeng Pambudi ${ }^{2}$, Erfan \\ Yudianto ${ }^{2}$ \\ Program Studi (S1) Pendidikan Matematika, FKIP, Universitas Jember (UNEJ) \\ Jln. Kalimantan 37, Jember 68121 \\ E-mail: imaniaaufi0@gmail.com
}

\begin{abstract}
Mathematical communication skills are needed to express ideas, messages, and ideas through written or oral. The research subjects were five students of class XII SMAN Ambulu who were categorized in van Hiele level. The results of the data analysis obtained were students with informal deduction had the ability to express mathematical ideas through written or oral, the ability to understand mathematical ideas both orally and in writing and the ability to use terms and notations to present data, and had the ability to present ideas. mathematics in solving or describing models of mathematical problems. Students of analysis have the ability to express mathematical ideas through oral, the ability to understand and evaluate mathematical ideas both orally and in writing, and are able to use mathematical terms and notations in presenting mathematical ideas. Visualization students are able to explain how to describe geometric transformations orally and are able to use notations and terms in presenting data.
\end{abstract}

Keywords: Mathematical Communication Skills, Van Hiele Level, Informal Deduction, Analysis, Visualization.

\section{PENDAHULUAN}

Pendidikan memiliki peran yang sangat penting dalam kemajuan suatu negara karena pendidikan merupakan faktor utama dalam memajukan sumber daya manusia. Beberapa kasus pendidikan di Indonesia yang masih berusaha diperbaiki pemerintah, yaitu rendahnya layanan pendidikan di Indonesia, rendahnya mutu pendidikan di Indonesia, rendahnya mutu pendidikan tinggi di Indonesia, dan rendahnya kemampuan literasi anak-anak Indonesia [1]. Sesuai dengan Undang-Undang No. 20 tahun 2003 yang ditetapkan oleh Departemen Pendidikan Nasional tentang sistem pendidikan nasional dijelaskan bahwa pendidikan adalah usaha sadar dan terencana untuk mewujudkan suasana belajar dan proses pembelajaran menjadi aktif mengembangkan potensi dirinya untuk memiliki spiritual keagamaan, pengendalian diri, kepribadian, kecerdasan, akhlak mulia, serta ketrampilan yang diperlukan dirinya, masyarakat, bangsa, dan negara.

Pendidikan matematika di sekolah bertujuan mempersiapkan peserta didik menghadapi perubahan dunia yang dinamis dengan menekankan pada penalaran logis, rasional dan kritis, serta memberikan keterampilan kepada mereka untuk mampu menggunakan matematika dan penalaran metematika dalam memecahkan berbagai masalah dalam kehidupan sehari-hari maupun mempelajari bidang ilmu lain [2]. Dalam Permendiknas Nomor 22 Tahun 2006 tentang Standar isi mata pelajaran matematika salah

\footnotetext{
${ }^{1}$ Mahasiswa S-1 Prodi Pendidikan Matematika FKIP Universitas Jember

${ }^{2}$ Dosen Pendidikan Matematika FKIP Universitas Jember
} 
satu tujuannya agar peserta didik memiliki kemampuan dalam mengkomunikasikan gagasan.

Kemampuan komunikasi matematis adalah suatu kemampuan mengemukakan ideide atau gagasan-gagasan terkait dengan matematika secara lisan maupun tertulis. Kemampuan komunikasi matematis siswa terdiri dari beberapa aspek dalam pengukurannya. Menurut National Council of Teachers of Mathematics aspek dalam pengukuran komunikasi matematis ialah sebagai berikut, Kemampuan mengekspresikan ide-ide matematis melalui tulisan, lisan, dan mendemonstrasikan serta menggambarkan secara visual, kemampuan memahami, menginterpretasikan dan mengevaluasi ide-ide matematis baik secara lisan, tulisan maupun dalam bentuk visual lainnya, kemampuan dalam menggunakan istilah-istilah, notasi-notasi matematika dan strukturnya untuk menyajikan ide-ide serta menggambarkan hubungan dan model-model situasi [3].

Disusunlah indikator kemampuan komunikasi matematis tulis yaitu siswa dapat menggambarkan transformasi geometri secara visual, siswa dapat mengklasifikasikan dan menjelaskan ciri transformasi melalui gambar, siswa dapat menjelaskan cara menentukan perubahan akibat transformasi, siswa dapat menggambarkan situasi transformasi geometri, Siswa dapat menggunakan istilah dan notasi untuk menyajikan data. Indikator kemampuan komunikasi matematis lisan adalah siswa dapat menjelaskan cara menggambarkan transformasi geometri, siswa dapat menjelaskan macam-macam transformasi dan menjelaskan cirinya melalui gambar, siswa dapat menjelaskan cara menentukan perubahan akibat transformasi, siswa menjelaskan situasi transformasi geometri, dan siswa dapat menjelaskan istilah dan notasi yang digunakan untuk menyajikan data.

Level van Hiele adalah pelevelan dalam pembelajaran geometri dengan mengklasifikasikan perkembangan anak dalam pemahaman geometri menjadi lima yaitu visualisasi, analisis, deduksi informal, deduksi, dan rigor. Seorang siswa tidak akan pada level yang tinggi jika tidak melewati level-level sebelumnya, sehingga setiap level pasti dilalui oleh seorang siswa dalam pemahaman geometri.

Berdasarkan uraian diatas maka dilakukan penelitian dengan judul "Profil Kemampuan Komunikasi Matematis dalam Menyelesaikan Masalah Geometri Ditinjau dari Level van Hiele", dengan tujuan mengetahui profil kemampuan komunikasi matematis siswa dalam menyelesaikan masalah geometri ditinjau dari level van Hiele.

\section{METODE PENELITIAN}

Jenis penelitian ini adalah penelitian deskriptif dengan pendekatan kualitatif. Penelitian ini dilaksanakan di SMAN Ambulu. Subjek pada penelitian ini adalah siswa kelas XII SMAN Ambulu, dengan level van Hiele visualisation, analisis, deduksi informal, deduksi, dan rigor. Tes level van Hiele terdiri dari 25 soal pilihan ganda yang dikutip dari Sunardi tahun 2000 [4]. Tes ini dikerjakan oleh siswa XII SMAN Ambulu, dengan waktu pengerjaan paling lambat 80 menit untuk mengelompokkan siswa sesuai dengan pelevelan van Hiele. Tes pelevelan yang digunakan pada penelitian ini berdasarkan pedoman yang dikembangkan oleh Usiskin [5]. Setiap level mempunyai lima pertanyaan, jika siswa menjawab tiga, atau lebih pertanyaan dengan benar pada suatu level paling bawah maka siswa tersebut memenuhi level tersebut dan dapat berlanjut ke level selanjutnya. Namun jika tidak dapat menjawab paling sedikit 3 dari 5 pertanyaan dengan benar maka siswa dikategorikan pada level sebelumnya. 
Tabel 1. Kriteria Penilaian pada Level Van Hiele

\begin{tabular}{cc}
\hline No. Soal & Level \\
\hline $1-5$ & Visualisasi \\
\hline $6-10$ & Analisis \\
\hline $11-15$ & Deduksi Informal \\
\hline $16-20$ & Deduksi \\
\hline $21-25$ & Rigor \\
\hline
\end{tabular}

Siswa yang memenuhi kriteria level van Hiele akan dijadikan subjek penelitian. Tes kemampuan komunikasi matematis ada dua yaitu tes kemampuan komunikasi matematis tulis dan tes kemampuan komunikasi matematis lisan. Tes kemampuan komunikasi matematis tulis berisi soal-soal yang terkait dengan masalah geometri yang dibuat sesuai dengan indikator yang telah ditentukan. Tes ini dikerjakan oleh subjek penelitian yang terdiri dari 3 soal uraian. Wawancara dilakukan untuk melengkapi dan menguatkan data-data yang dibutuhkan peneliti dan untuk menguji kemampuan komunikasi lisan.

\section{HASIL DAN PEMBAHASAN}

Pelaksanaan penelitian diadakan dengan mengunjungi beberapa rumah siswa, namun sebelum itu ada beberapa hal yang perlu dilakukan yaitu menyiapkan instrumen yang digunakan dalam penelitian dan memvalidasi instrumen tersebut dan berkoordinasi dengan siswa terkait kesediaannya mengikuti penelitian. Responden dalam penelitian ini adalah siswa kelas XII di SMAN Ambulu. Subjek penelitian yang dipilih ada lima siswa yang telah dikategorikan menurut level van Hiele. Setelah mengkategorikan siswa, dipilih satu siswa secara acak pada setiap level van Hiele namun untuk level visualisasi dipilih dua orang siswa dan deduksi informal juga dipilih dua orang siswa.

Berikut adalah kutipan jawaban siswa visualisasi

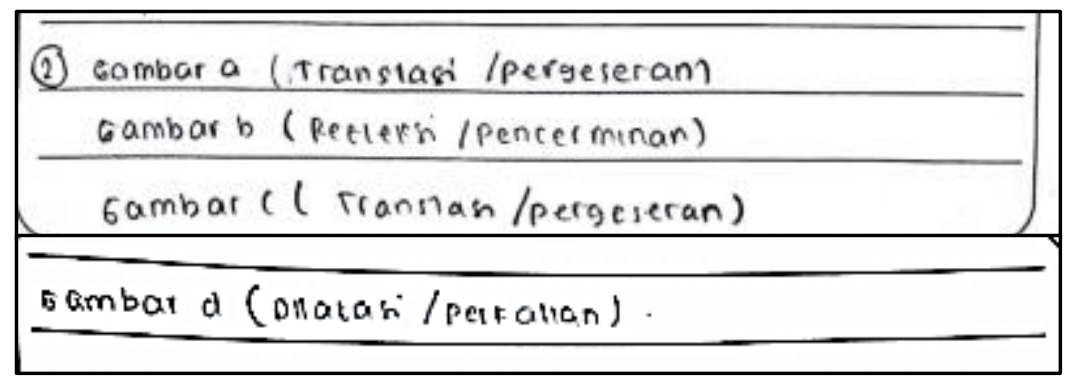

Gambar 1. Jawaban SV2 pada Soal Nomor 2

P204 : Bagaimana mengklasifikasikan macam transformasi geometri melalui sebuah gambar dan sebutkan cirinya?

SV204 : Yang a refleksi karena gambarnya seperti dicerminkan titiknya sama. Yang b refleksi karena ada garis cermin karena jarak benda ke cermin sama dengan jarak bayangan ke cermin. Yang c translasi karena bendanya itu cuma bergeser dan titiknya tetap. Yang d dilatasi atau perbesaran karena disitu bendanya berubah menjadi lebih besar. 
Pekerjaan diatas merupakan jawaban dari siswa visualisasi, pada gambar 1 siswa sudah dapat menyebutkan macam-macam transformasi namun untuk menuliskan cirinya siswa belum mampu. Hal itu sejalan dengan penelitian yang dilakukan van Hiele bahwa level visualisasi siswa baru mengenali bentuk-bentuk geometri dengan melihat contohnya tetapi belum dapat menyebutkan sifat dari bangun geometri tersebut, pada tahap ini siswa menerima materi geometri berdasarkan hafalan, bukan melaui penalaran dan pengertian [6]. Namun berbeda saat melakukan tes wawancara untuk mengetahui kemampuan komunikasi matematis lisan, siswa sudah dapat menyebutkan macam-macam transformasi geometri berserta cirinya dengan tepat.

Secara singkat ketercapaian siswa terhadap indikator kemampuan komunikasi matematis adalah sebagai berikut.

Tabel 2. Pencapaian Indikator Kemampuan Komunikasi Matematis Siswa

\begin{tabular}{|l|l|l|l|l|l|l|l|l|l|l|l|}
\hline \multirow{2}{*}{$\begin{array}{l}\text { Subjek } \\
\text { Penelitian }\end{array}$} & \multicolumn{2}{|l|}{ Indikator 1 } & \multicolumn{2}{|l|}{ Indikator 2 } & \multicolumn{2}{l|}{ Indikator 3 } & \multicolumn{2}{l|}{ Indikator 4 } & \multicolumn{2}{|l|}{ Indikator 5 } \\
\cline { 2 - 14 } & Tulis & Lisan & Tulis & Lisan & Tulis & Lisan & Tulis & Lisan & Tulis & Lisan \\
\hline SV1 & $\mathrm{x}$ & $\sqrt{ }$ & $\mathrm{x}$ & $\mathrm{x}$ & $\mathrm{x}$ & $\mathrm{x}$ & $\mathrm{x}$ & $\mathrm{X}$ & $\sqrt{ }$ & $\sqrt{ }$ \\
\hline SV2 & $\mathrm{x}$ & $\sqrt{ }$ & $\mathrm{x}$ & $\sqrt{ }$ & - & $\mathrm{x}$ & $\mathrm{x}$ & $\mathrm{X}$ & $\sqrt{ }$ & $\sqrt{ }$ \\
\hline SA & $\mathrm{x}$ & $\sqrt{ }$ & $\sqrt{ }$ & $\sqrt{ }$ & $\sqrt{ }$ & $\sqrt{ }$ & $\mathrm{x}$ & $\mathrm{X}$ & $\sqrt{ }$ & $\sqrt{ }$ \\
\hline SDI1 & $\sqrt{ }$ & $\sqrt{ }$ & $\mathrm{x}$ & $\mathrm{x}$ & $\mathrm{x}$ & $\mathrm{x}$ & $\mathrm{x}$ & $\mathrm{X}$ & $\sqrt{ }$ & $\sqrt{ }$ \\
\hline SDI2 & $\sqrt{ }$ & $\sqrt{ }$ & $\sqrt{ }$ & $\sqrt{ }$ & $\mathrm{x}$ & $\mathrm{x}$ & $\sqrt{ }$ & $\sqrt{ }$ & $\sqrt{ }$ & $\sqrt{ }$ \\
\hline
\end{tabular}

Keterangan:

$\sqrt{ }=$ Subjek mampu menjawab dan mampu memenuhi indikator

$\mathrm{x} \quad=$ Subjek mampu menjawab tetapi tidak mampu memenuhi indikator

- $\quad=$ Subjek tidak mampu menjawab

Pada penelitian ini, diambil dua subjek penelitian siswa visualisasi dengan kode SV1 dan SV2. Siswa SV1 dan SV2 dapat menjelaskan cara menggambarkan transformasi geometri dan menjelaskan istilah dan notasi yang digunakan dalam menyajikan data. Perbedaan terletak pada indikator siswa dapat menjelaskan macam transformasi dan ciri transformasi geometri hanya dicapai oleh siswa SV2. SV2 mampu menyebutkan macam transformasi dan ciri transformasi 3 gambar permasalahan dengan benar sedangkan SV1 hanya mampu menyebutkan dengan benar 2 gambar permasalahan. Sehingga siswa visualisasi mampu memenuhi indikator menjelaskan mengklasifikasikan transformasi geometri dan menjelaskan cirinya.

Dalam penelitian ini hanya ditemukan satu siswa dengan level analisis dengan kode SA. Pada kemampuan komunikasi matematis tulis siswa analisis sudah mampu memenuhi indikator siswa dapat mengklasifikasikan dan menyebutkan ciri-ciri transformasi geometri melalui sebuah gambar, siswa dapat menjelaskan cara menentukan perubahan transformasi geometri, dan siswa dapat menggunakan istilah-istilah dan notasi-notasi untuk menyajikan data. Hal itu juga sejalan dengan pendapat Baeti dan Murtalib bahwa siswa analisis dapat memberitahukan sifat-sifat dalam sebuah gambar bangun datar [7]. Pada tes kemampuan komunikasi matematis lisan, siswa analisis mampu memenuhi indikator siswa dapat menjelaskan cara menggambar transformasi geometri, siswa dapat menjelaskan macam transformasi geometri dan menyebutkan cirinya melalui gambar, siswa dapat menjelaskan cara menentukan perubahan transformasi geometri, dan siswa mampu menjelaskan istilah dan notasi yang digunakan dalam menyajikan data.

Pada penelitian ini, diambil 2 subjek penelitian siswa deduksi informal dengan kode SDI1 dan SDI2. Berdasarkan analisis data pada subbab sebelumnya, terdapat perbedaan kemampuan komunikasi matematis SDI1 dan SDI2. Dalam hal itu, SDI2 memiliki 
kemampuan komunikasi matematis yang lebih unggul dibandingkan dengan SDI. Perbedaannya SDI1 belum mampu mengklasifikasikan dan menyebutkan ciri transformasi geometri karena dari 4 permasalahan yang diberikan hanya dapat menjawab 2 permasalahan dengan tepat sedangkan SDI2 mampu mengklasifikasikan dan menyebukan ciri transformasi geometri karena SDI2 mampu menjawab 3 gambar permasalahan dengan tepat. Sama halnya dengan pendapat Baeti dan Murtalib bahwa siswa deduksi informal dapat menjelaskan sifat-sifat yang dimiliki suatu bangun datar [7].

Perbedaan lain juga pada indikator menggambarkan situasi transformasi geometri, karena SDI1 sudah dapat memaknai situasi permasalahan yang ada pada soal namun dalam pengaplikasian rumus SDI1 masih mengalami kesulitan berbeda dengan SDI2 yang sudah mampu memaknai permasalahan dan mengaplikasikan rumus yang akan digunakan. Hal itu sesuai dengan Muhassanah, dkk. yang menyatakan siswa level deduksi informal mampu menggunakan konsep model matematika yang berhubungan dengan suatu objek [8].

\section{KESIMPULAN}

Berdasarkan pemaparan diatas, siswa visualisasi memiliki kemampuan komunikasi tulis yaitu dapat mengekspresikan ide-ide matematis melalui lisan dan mendemostrasikannya, mampu menggunakan istilah-istilah dan notasi-notasi dalam menyajikan suatu data. Sedangkan kemampuan komunikasi matematis tulisnya yaitu siswa mampu memahami ide-ide matematika dan mampu menjelaskan istilah-istilah dan notasi-notasi matematika yang digunakan dalam menyajikan data.

Siswa analisis memiliki kemampuan komunikasi matematis tulisnya adalah mampu memahami, menginterpretasikan dan mengevaluasi ide-ide matematika dan mampu menggunakan istilah-istilah dan notasi-notasi matematika dalam menyajikan ide matematika. Sedangkan untuk kemampuan komunikasi matematis lisan yaitu dapat mengekspresikan ide-ide matematis melalui lisan dan mendemostrasikannya, mampu memahami dan mengevaluasi ide-ide matematis baik secara lisan dan mampu menjelaskan istilah-istilah dan notasi-notasi matematika yang digunakan dalam menyajikan data.

Siswa deduksi informal memiliki kemampuan komunikasi matematis tulisnya adalah mampu mengekspresikan ide-ide matematika melalui tulisan dan mendemonstrasikan serta menggambarkan secara visual, mampu memahami ide-ide matematika, dapat menggambarkan situasi transformasi geometri, dan mampu menggunakan istilah-istilah dan notasi-notasi matematika dalam menyajikan ide matematika. Sedangkan untuk kemampuan komunikasi matematis lisan yaitu dapat mengekspresikan ide-ide matematis melalui lisan dan mendemostrasikannya, mampu memahami ide-ide matematis baik secara lisan, dapat menggambarkan situasi transformasi geometri, dan mampu menjelaskan istilah-istilah dan notasi-notasi matematika yang digunakan dalam menyajikan data.

Berdasarkan hasil penelitian yang didapatkan, terdapat beberapa saran sebagai berikut. Bagi siswa, dapat dijadikan pedoman untuk lebih meningkatkan kemampuannya dalam mengerjakan soal-soal yang berbasis masalah. Bagi guru, dapat dijadikan pertimbangan dalam memberikan pembelajaran pada bidang geometri. Bagi penelitian selanjutnya, dapat menggembangkan indikator kemampuan komunikasi matematis menjadi lebih kreatif. 


\section{DAFTAR PUSTAKA}

[1] Widodo, H. (2016). Potret Pendidikan Di Indonesia Dan Kesiapannya Dalam Menghadapi Masyarakat Ekonomi Asia (Mea). Cendekia: Journal of Education and Society, 13(2), 293. https://doi.org/10.21154/cendekia.v13i2.250

[2] Hadi, S. (2017). Pendidikan Matematika Realistik. Jakarta: Rajawali Pers. https://doi.org/10.1145/2505515.2507827

[3] National Council of Teachers of Mathematics. (2000). Principles and Standards for School Mathematics. Reston, VA: NCTM.

[4] Sunardi. (2000). Pengembangan Model Pembelajaran Geometri Berbasis Teori Van Hiele. Mathedu: Jurnal Pendidikan Matematika, 1(2), 71-82.

[5] Kusniati. (2011). Analisis Kesalahan Siswa dalam Menyelesaikan Soal Materi Pokok Segiempat Menurut Tingkat Berpikir Geometri Van Hiele. Universitas Semarang.

[6] Aisyah, N., Hawa, S., Somakim, Purwoko, Hartono, Y., \& AS, M. (2007). Pembelajaran Matematika Sekolah Dasar. Jakarta: Dirjen Pendidikan Tinggi.

[7] Baeti, N., \& Murtalib., (2018). Analisis Keterampilan Geometri Siswa dalam Memecahkan Masalah Geometri Berdasarkan Tingkat Berpikir van Hiele Di Mts Muhammadiyah 1 Malang. Jurnal Pendidikan Matematika, 2(2), 39-50

[8] Muhassanah, N., dkk. (2014). Analisis Keterampilan Geometri Siswa dalam Memecahkan Masalah Geometri Berdasarkan Tingkat Berpikir van Hiele. Jurnal Elektrik Pembelajaran Matematika, 2(1), 54-66 